East African Medical Journal Vol. 87 No. 4 April 2010

PERSISTENT HEPATITIS A INFECTION: CASE REPORT

M. Ngunga, MBChB, MMed and M.V. Shah, MBChB, MMed, Consultant Physician and Gastroenterologist, The Aga Khan University Hospital Nairobi, P.O. Box 30270-00100, Nairobi, Kenya

Request for reprints to: Dr. M. Ngunga, Aga Khan University Hospital Nairobi, P.O. Box 30270-00100, Nairobi, Kenya

\title{
PERSISTENT HEPATITIS A INFECTION: CASE REPORT
}

\author{
M. NGUNGA and M.V. SHAH
}

\begin{abstract}
SUMMARY
Hepatitis A viral infection resolves completely within six months in all patients infected. The case presented is a rare one that took fifteen months to resolve from hepatitis A viral infection.
\end{abstract}

\section{INTRODUCTION}

Hepatitis A has plagued human kind for centuries by causing acute hepatitis associated with significant morbidity and occasional mortality. The hepatitis A virus (HAV) was identified in 1973 and since then extensive research has led to the development of vaccines; reducing the mortality and the morbidity of the disease. Normally HAV infection is an acuteillness that resolves in days to weeks except for few cases that may progress to fulminant hepatitis sometimes with fatal outcome (1). We present a rare case of persistent HAV infection that may shed some lightintounknown virology of the hitherto benign virus.

\section{CASE REPORT}

A 28 year old man was presented to this hospital in March 2007 with three months history of jaundice and pruritus. Symptoms started with a febrile illness, anorexia and he noticed darkening of the urine. There was no vomiting and he did not report any change in the stool colour. He reported good health prior to this and has not been on any medication neither has he required hospitalisation or blood transfusion. He works in a cement factory where he deals with machine maintenance using lubrication oil. He is married with one child and does not report anyone at his home or work place with icteral or febrile illness. He does not use any drugs of abuse and does not consume alcohol. He had not travelled anywhere outside the country or interacted with world animals. There was no family history of any chronic illness.

On examination he was awake and alert without any features of encephalopathy and his oxygen saturation was $98 \%$ while breathing ambient air with a respiratory rate of 20 breaths per minute. He did not have any visible drug injection sites. He had scleral and palmer jaundice. He was not pale, did not have any palpable nodes and did not have features of chronic liver disease. The pulse was regular at 70 $\mathrm{bpm}$ and blood pressure was $112 / 60 \mathrm{mmHg}$. The temperature was $36.3^{\circ} \mathrm{C}$. Abdominal examination revealed excoriation marks in the anterior abdominal wall. The abdomen was soft to palpation with some tenderness over the right hypochondrium. The liver was palpable $2 \mathrm{~cm}$ below the right costal margin with a smooth tender edge and a span of $12 \mathrm{~cm}$. The spleen was not palpable and there were no other palpable masses. There was no ascitis. Bowel sounds were normal and hernial orifices were intact. Neurological, respiratory and cardiovascular examinations were normal. A diagnosis of acute hepatitis was made probably of infectious aetiology. An obstructive cause could not be ruled out.

The patient was admitted for evaluation. He was investigated and discharged on the third hospital day on cholestyramine $4 \mathrm{~g}$ three times a day, B1/B6/B12 multivitamin complex and advised to rest at home. 
Table 1

The liver function tests before admission, at admission and during follow up

\begin{tabular}{|c|c|c|c|c|c|c|c|c|c|}
\hline Date & $\begin{array}{l}\text { Total } \\
\text { bilirubin } \\
(\mathrm{mmol} / \mathrm{L})\end{array}$ & $\begin{array}{l}\text { Direct } \\
(\mathrm{mmol} / \mathrm{L})\end{array}$ & $\begin{array}{l}\text { ALP } \\
(\mathrm{u} / \mathrm{L})\end{array}$ & $\begin{array}{l}\text { GGT } \\
(\mathrm{u} / \mathrm{L})\end{array}$ & $\begin{array}{l}\text { SGO } \\
\mathrm{T} \\
(\mathrm{u} / \mathrm{L})\end{array}$ & $\begin{array}{l}\text { SGPT } \\
(\mathrm{u} / \mathrm{L})\end{array}$ & $\begin{array}{l}\text { T. protein } \\
(\mathrm{g} / \mathrm{L})\end{array}$ & $\begin{array}{l}\text { Albumin } \\
(\mathrm{g} / \mathrm{L})\end{array}$ & INR \\
\hline Normal & $1-17$ & $<4$ & $60-120$ & $<50$ & $<37$ & $<40$ & $60-80$ & $32-52$ & \\
\hline $13 / 04 / 2007$ & 391 & 223 & 236 & 64 & 103 & 194 & & & \\
\hline $21 / 03 / 2007$ & 547 & 268 & 412 & 17 & 163 & 172 & & & \\
\hline $24 / 03 / 2007$ & & & & & & & 66 & 33 & 1.36 \\
\hline $27 / 0312007$ & & & & & & & & & 1.25 \\
\hline $20 / 04 / 2007$ & 444 & 180 & 387 & 20 & 208 & 229 & & & 1.43 \\
\hline $18 / 05 / 2007$ & 436 & 196 & 335 & 22 & 137 & 142 & 62 & 34 & 1.8 \\
\hline $29 / 06 / 2007$ & 480 & 216 & 391 & 24 & 210 & 170 & 70 & 33 & \\
\hline $27 / 07 / 2007$ & 424 & 201 & 449 & 29 & 185 & 135 & 68 & 32 & 2.4 \\
\hline $24 / 08 / 2007$ & 429 & 216 & 402 & 21 & 227 & 192 & 72 & 35 & 2.65 \\
\hline $21 / 09 / 2007$ & 408 & 208 & 428 & 24 & 255 & 237 & & & \\
\hline $02 / 11 / 2007$ & 385 & 196 & 391 & 26 & 248 & 212 & 67 & 35 & 2.47 \\
\hline $30 / 11 / 2007$ & 401 & 196 & 437 & 28 & 290 & 240 & 73 & 34 & 3 \\
\hline $11 / 01 / 2008$ & 382 & 179 & 437 & 32 & 290 & 206 & 64 & 32 & 3.3 \\
\hline $13 / 03 / 2008$ & 332 & 175 & 517 & 34 & 182 & 140 & 66 & 31 & 2.7 \\
\hline $15 / 06 / 2009$ & 5 & 1 & 118 & 52 & 27 & 34 & 77 & 41 & 1.1 \\
\hline
\end{tabular}

The creatinine was $48 \mathrm{mmol} / \mathrm{L}$, BUN $1.8 \mathrm{mmol} / \mathrm{L}$, $\mathrm{Na} 139 \mathrm{mmol} / \mathrm{L}$ and hypokalemia of $2.9 \mathrm{mmol} / \mathrm{L}$ that was replaced with KCI infusion over the next 24 hours and normalised. The haemoglobin was $14.8 \mathrm{~g} / \mathrm{dL}$, white cell count of $5.3 \times 10^{9}$ with normal distribution and platelets of $327 \times 10^{9}$. The blood glucose was $4.5 \mathrm{mmol} / \mathrm{L}$ at admission and remained normal during the course of follow up. Elisa screen for $\mathrm{HBsAg}$ and $\mathrm{HCV}$ antibody were negative, so was HIV I and II serology. A liver ultrasound done showed homogenous echogenicity of the liver with no dilated ducts. The gall bladder was collapsed and the common bile duct was normal. Urinalysis done at the time of admission showed bilirubin +++ and trace albumin with rest of the parameters being normal. Hepatitis A Ig G and Ig M antibodies were positive and titres at admission and during follow up are as shown below: -

\begin{tabular}{lll}
\hline Date & $\operatorname{IgM}$ & $\operatorname{IgG}$ \\
\hline $24 / 03 / 2007$ & 4.36 & 0.093 \\
& (Reactive) & (Reactive) \\
$21 / 09 / 2007$ & $\begin{array}{l}1.76 \\
\text { (Reactive) }\end{array}$ \\
$15 / 06 / 2009$ & 0.69 & 0.091 \\
& (Non-reactive) & (Reactive) \\
\hline
\end{tabular}

Other causes of hepatitis had to be ruled out after the patients liver function tests failed to improve after three months. Autoimmune screen was done that wasnegative for anti-nuclear antibodies (ANA), anti- mitochondrial antibodies (AMA) and anti-smooth muscle antibodies (ASMA). Serum ferration was normal at $125.3 \mathrm{ng} / \mathrm{ml}$ (16-323). Alpha-lantitrypsin was normal at $197 \mathrm{mg} / \mathrm{dL}(90-200)$ with EBV IgM antibodies being negative. The IgG was reactive. Serum ceruloplasmin level was marginally elevated at $58.9 \mathrm{mg} / \mathrm{dL}(20-60)$ that can be expected following acutehepatitis. Haemoglobinelectrophoresis showed $\mathrm{Hb}$ AA.

The patient declined a liver biopsy. He waslost to follow up and was called up to review his progress. As can be noted in the table above the liver function test normalised two years later with normal bilirubin and transaminase levels. The INR was 1.1. The hepatitis A Ig $G$ antibody remained positive while the Ig M was now negative.

\section{DISCUSSION}

Acute hepatitis A virus (HAV) infection is usually a self-limited disease conferring lifelong immunity. The disease affects the entire human race with higher prevalence in the developing world compared to the developed world. The incidence rates are 5.9 per 100,000 and 1.2 per 100,000 respectively $(2,3)$. The above surveillance reports also confirm more than $90 \%$ reduction in the incidence of HAV infection in the 1990s after the introduction of the vaccine and improved living conditions.

HAV is spread via the foecal-oral route, and is more prevalent in low socioeconomic areas in which lack of adequate sanitation and poor hygienic 
practices facilitate spread of the infection. Other risk factors include sexual and household contact with another person with hepatitis A, homosexual activity in men, food or waterborne outbreaks, child or employee in a daycare center and injection drug use (4). Maternal-foetal transmission has not been reported.

Injury to the liver is secondary to the host's immune response. Replication of HAV occurs exclusively within the cytoplasm of the hepatocyte, where the virus causes a non cytopathic infection. Hepatocellular damage and destruction of infected hepatocytes is mediated by HLA-restricted, HAVspecific CD8+ Tlymphocytes and natural killer cells. Interferon gamma promotes the clearance of infected hepatocytes. An excessive host response (observable clinically by a marked degree of reduction of HAV RNA during acute infection) is associated with severe hepatitis.

Fulminant hepatitis is uncommon but has been described in some settings such as in patients with preexisting chronic hepatitis C (5). Chronic liver disease does not occur except in rare individuals in whom hepatitis A virus infection serves as a trigger for the development of autoimmune hepatitis. Infection also tends to be more severe in adults compared to children but neither concomitant hepatitis B or $\mathrm{C}$ infection or older age are known risk factors for persistent infection.

One of the atypical presentations of HAV infection is cholestatic hepatitis. The clinical course in this setting is characterised by marked jaundice, pruritus, fever, weight loss, diarrhoea, and malaise. Biochemical and serologic abnormalities typically show marked elevation of the serum bilirubin (often $>170 \mathrm{mmol} / \mathrm{L}$ ) and alkaline phosphatase, an elevated serum cholesterol, minimal elevation of serum aminotransferases, and often IgM anti-HAY antibodies. Peak bilirubin levels may be reached in the eighth week or later. The jaundice and pruritus may last for 12 weeks or more, but are followed by complete recovery (6). In the case series quoted above involving six patients cholestasis persisted for 12 weeks with complete recovery but our patient had bilirubin levels more than 20 times of the normal and elevation of transaminases more than five times normal for at least year.

The other atypical form is a relapsing form of hepatitis seen in 3-20\% of patients with acutehepatitis A (7-9). Bilirubin and transaminase levels remain elevated for 3-5 weeks then normalise for a similar duration of time. A relapse occurs in approximately
3 weeks mimicking the initial episode but usually milder. The entireillness lasts approximately 40 weeks and HA V Ig M may remain positive. Our patient did not show any signs of relapse but a persistent illness with elevated bilirubin, alkaline phosphatase and transaminases.

The patient did not exhibit any extra-hepatic disease. During the course of his disease there were no skin lesions and he did not have arthritis. The autoimmune markers were negative so autoimmune hepatitis was unlikely.

The patient declined a liver biopsy that would probably have shed some light as to the histological findings contributing to his illness. However, we have no doubt that hepatitis A was responsible for the pathology. This is the first case to confirm persistent HAV infection for more than a year. The patient did not exhibit any risk factors for persistent disease; therefore viral factors may be responsible for his protracted illness.

Disclosures: There are no disclosures relating to this article.

\section{REFERENCES}

1. Taylor, R.M., et al. Fulminant hepatitis A virus injection in the United States: Incidence, prognosis, and outcomes. Hepatology. 2006; 44: 1589-1597.

2. Wasley, A., Samandari, T. and Bell, B.P. Incidence of hepatitis $A$ in the United States in the era of vaccination. J. Amer. Med. Assoc. 2005. 294: 194-201.

3. Cuif, H., Zheng S.C., et al. Hepatitis A surveillance and vaccine use in China from 1990 through 2007. J. Epidemiol. 2009;19: 189-195.

4. Wasley, A. Grytdal, S. and Gallagher, K. Surveillance for acute viral hepatitis- United States, 2006. MMWR Surveill. Summ. 2008. 57: p. 1-24.

5. Vento, S., et al. Fulminant hepatitis associated with hepatitis A virus super-infection in patients With chronic hepatitis C. New. Engl. J. Med. 1998;338: 286890.

6. Gordon, S.C., et al. Prolonged intrahepatic cholestasis secondary to acute hepatitis A. Ann. Intern. Med. 1984.101: 635-637.

7. Schiff, E.R. Atypical clinical manifestations of hepatitis A. Vaccine. 1992. 10(Suppl 1): p. S18-20.

8. Glikson, M., et al. Relapsing hepatitis A review of 14 cases and literature survey. Medicine (Baltimore). 1992; 71: 14-23.

9. Kassas, A.L., et al. Polyphasic und protracted patterns of hepatitis A injection: a retrospective study. Acta. Med. Hung. 1994; 50: 93-98. 